Agnieszka Graff

Uniwersytet Warszawski

\title{
„Żydofemina"? O złożonej relacji między żydowskim pochodzeniem, żydowską tożsamością, lewicowością i feminizmem drugiej fali w Stanach Zjednoczonych
}

Dunktem wyjścia moich rozważań jest pewien fakt historyczny. Wśród kobiet, które tworzyły amerykański feminizm drugiej fali - zarówno liberalny, reformatorski, jak i radykalny, zwany ruchem wyzwolenia kobiet - bardzo wiele miało żydowskie korzenie. Z jednej strony faktu tego nie można podważyć - tak po prostu było, zwłaszcza na Wschodnim Wybrzeżu, a szczególnie w Nowym Jorku. Można się spierać o skalę zjawiska, jego znaczenie, przyczyny i konsekwencje, fakt pozostaje jednak bezsporny. Z drugiej strony bardzo rzadko bywa on przedmiotem namysłu w opracowaniach historycznych dotyczących ruchu kobiecego drugiej połowy XX wieku' ${ }^{1}$.

Czy warto o tym fakcie mówić? Czy wypada to robić zwłaszcza w Polsce? Kłopot polega na tym, że, stając się przedmiotem dyskursu naukowego, ów fakt szybko okazuje się czymś więcej niż faktem, a mianowicie polityczną insynuacją. Pisząc o nim, nieuchronnie ryzykuję, że wpiszę się (lub zostanę wbrew woli wpisana) w żywy nad Wisłą myślowy schemat o nazwie żydokomuna, używany do dyskwalifikowania myśli lewicowej i podsycania antysemityzmu. Jego cechą konstytutywną jest wrogość wobec opisywanych wyborów ideologicznych i odmowa oddania głosu osobom, które tych wyborów dokonały². O skali ryzyka przekonał się niedawno Paweł Śpiewak,

${ }^{1}$ Najważniejsze książki proponujące syntetyczne ujęcie drugiej fali feminizmu jako ruchu społecznego i zjawiska kulturowego różnią się pod wieloma względami, ale żadna z nich nie podejmuje tej kwestii. Chodzi o następujące pozycje: Flora Davis, Moving the Mountain. The Women's Movement in America since 1960, University of Illinois Press, Urbana 1999; Sara Evans, Tidal Wave. How Women Changed America at Century's End, The Free Press, New York 2003; Ruth Rosen, The World Split Open: How the Modern Women's Movement Changed America, Viking, New York 2000; Sheila Tobias, Faces of Feminism. An Activist's Reflection on the Women's Movement, Westview Press, Boulder Co. 1997.

${ }_{2}$ Zob.: Anna Zawadzka, „Żydokomuna”. Szkic do socjologicznej analizy źródeł historycznych; dostępne przez: http://www.archiwumetnograficzne.edu.pl/downloads/zydokomuna_zawadzka.pdf (20.03.2013). Jak pisze Zawadzka, 'żydokomuna' to „stereotyp na 
autor książki Żydokomuna (do sporu, jaki towarzyszył ukazaniu się tej pracy, jeszcze wrócę, stanowi on bowiem istotny kontekst powstania niniejszego tekstu).

Nie ulega wątpliwości, że ten demaskatorski schemat bardzo łatwo przenieść na teren debaty o feminizmie. Jako projekt polityczny i społeczny, a także jako dyskurs naukowy feminizm z trudem zyskuje we współczesnej Polsce legitymację, a jeśli tak się dzieje, to w dużej mierze dlatego, że został przypisany do kategorii dyskursów modernizacyjnych, liberalnych, zachodnich, uniwersalistycznych, przy jednoczesnym przemilczeniu jego lewicowych korzeni ${ }^{3}$. Przypomnienie, że ogromny wkład w budowanie teoretycznych i organizacyjnych podstaw feminizmu miały amerykańskie Żydówki - i to Żydówki o lewicowych poglądach - może ten wizerunek nadwyrężyć. Czy warto podejmować takie ryzyko? Czy fakt, o którym tu mowa, ma w ogóle jakieś znaczenie dla historii amerykańskiego (a pośrednio - światowego) feminizmu? Masowy akces Żydówek do ruchu wyzwolenia kobiet pod koniec lat sześćdziesiątych XX wieku jest niewątpliwie interesujący z punktu widzenia badaczy historii mniejszości żydowskiej w USA, a zwłaszcza z punktu widzenia historii amerykańskich Żydówek - uniwersalistycznie rozumiany feminizm stanowi tu niejako etap pośredni między tradycyjną tożsamością żydowską a żydowskim feminizmem ${ }^{4}$. Czy jednak ma to jakieś znaczenie $\mathrm{z}$ punktu widzenia historii ruchu kobiecego?

\section{Przeoczone Żydówki}

Skalę zjawiska - a także skalę milczenia, jakie towarzyszy mu w pracach historycznych dotyczących drugiej fali - unaocznia tekst Daniela Horowitza zamieszczony w pionierskiej antologii tekstów o Żydówkach w powojennej historii Stanów Zjednoczonych ${ }^{5}$. Horowitz analizuje ewolucję stosunku do żydowskich korzeni, jaka zaszła u Betty Friedan, autorki słynnej Mistyki

trwałe wpisany w antysemicki język Drugiej Rzeczypospolitej” [s. 5], pielęgnowany w celach politycznych przez twórców obecnej polityki historycznej, a zawierający niewypowiedziane założenia zarówno antysemickie, jak i antykomunistyczne. Pojęcie to „odsłania logikę dominacji”, może być bowiem sensownie używane wyłącznie w obrębie języka większości, która odmawia członkom mniejszości prawa do samoidentyfikacji [s. 12-13].

3 Ciekawie (i krytycznie) pisze o tych mechanizmach Agnieszka Mrozik w książce $\mathrm{Aku}$ szerki transformacji. Kobiety literatura i władza $w$ Polsce po 1989 roku (Lupa Obscura, Warszawa 2012, s. 396-406).

4 Zob.: Joyce Antler, The Journey Home. How Jewish Women Shaped Modern America, Shocken Books, New York 1997, rozdział 9: Feminist Liberations, s. 259-284.

5 Daniel Horowitz, Jewish Women Remaking American Feminism/Women Remaking American Judaism. Reflections on the Life of Betty Friedan, [w:] eds. Hasia R. Diner, Shira Kohn, Rachel Karson, A Jewish Feminine Mystique? Jewish Women in Postwar America, Rutgers University Press, New Brunswick 2010, s. 235-256. 
kobiecości (1963), założycielki i wieloletniej przewodniczącej Krajowej Organizacji na rzecz Kobiet (NOW), kluczowej postaci liberalnego nurtu feminizmu w USA ${ }^{6}$ (do Friedan i relacji między jej żydowską tożsamością, a zaangażowaniem w ruchy lewicowe w latach czterdziestych jeszcze wrócę).

Zacznijmy od tego, co w artykule Daniela Horowitza może szokować, czyli od sposobu wprowadzenia kwestii żydowskiej do rozmowy o feminizmie. Otóż autor stawia dwa pytania, sformułowane w dość pokrętny i prowokacyjny sposób: „,po] pierwsze, dlaczego tak mało jest badań naukowych dotyczących żydowskiej tożsamości [Jewishness] Żydówek, które w latach sześćdziesiątych były feministkami? I po drugie, jak wyjaśnić nieproporcjonalnie wielki odsetek feministycznych pisarek i aktywistek z lat sześćdziesiątych, które - być może nie za sprawą zbiegu okoliczności - były Żydówkami?” Horowitz zostawia te pytania bez odpowiedzi; mają one wybrzmieć jako pytania retoryczne. Jest to retoryka charakterystyczna dla insynuacji, bo autor wyraźnie przecież sugeruje, że ktoś tu coś ukrywa i że ma po temu swoje powody, które należałoby wyjaśnić. Dalej podaje kilka dowodów na ową „dysproporcję". Wymienia nazwy kobiecych a zarazem żydowskich (choć niekoniecznie lewicowych i feministycznych) ruchów na rzecz sprawiedliwości społecznej, poprzedzających drugą falę feminizmu (Hadassah; Emma Lazarus Federation of Jewish Women's Clubs; National Council of Jewish Women) i zwraca uwagę na skalę udziału Żydówek w feministycznym nurcie Frontu Ludowego. Następnie przytacza imponującą listę wybitnych Żydówek-feministek z lat sześćdziesiątych i późniejszych. Jest na niej trzydzieści jeden nazwisk, m.in.: Betty Friedan, Bella Abzug, Susan Faludi, Judith Butler, Judy Chicago, Naomi Weisstein, Robin Morgan, Susan Gubar, Carol Gilligan, Florence Howe, Gerda Lerner, Andrea Dworkin, Gloria Steinem.

Gdyby autor nie był amerykańskim Żydem o lewicowych poglądach, można by przypuszczać, że listę Żydówek serwuje nam zaciekły konserwatysta i antysemita, demaskator, który ujawnia fakt jego zdaniem kompromitujący. Komuś, kto czyta ową listę w Warszawie, skojarzenie z żydokomuną nasuwa się samo. A jednak skojarzenie to należy zawiesić jako nieadekwatne do amerykańskich kontekstów. Jeśli bowiem Horowitz coś insynuuje, to tylko to, że badaczki drugiej fali feminizmu dopuściły się przeoczenia, wynikającego być

${ }^{6}$ Daniel Horowitz to autor kontrowersyjnej biografii Friedan: Betty Friedan and the Making of the Feminine Mystique (University of Massachusetts Press, Amherst 1998). Autor ujawnia radykalnie lewicowe sympatie z młodości późniejszej założycielki liberalnego feminizmu, otwierając tym samym temat zapomnianej łączności między starą (ekonomiczną) a nową (kulturową) lewicą w USA, a także związków między starą lewicą a ruchem kobiecym. Szerzej na ten temat: Agnieszka Graff, Mistyka, mistyfikacja, lustracja, czyli kilka słów o „Feminine Mystique” Betty Friedan, „Res Publica Nowa” 2008, nr 4, s. 138-144.

7 Daniel Horowitz, Jewish Women..., op. cit., s. 245. Tam, gdzie nie zaznaczono inaczej, cytaty ze źródeł obcojęzycznych podaję w tłumaczeniu własnym. 
może z odziedziczonej po latach sześćdziesiątych uniwersalistycznej optyki samych drugofalowych feministek. Jest to przeoczenie o tyle dziwaczne, że w ostatnich dekadach optykę tę gruntownie przezwyciężono, tak w teorii feminizmu, jak w badaniach nad jego historią ${ }^{8}$. W ostatniej dekadzie ukazało się wiele prac historycznych i antropologicznych, które przywróciły pamięć o nurtach amerykańskiej drugiej fali definiowanych ze względu na rasę i etniczność 9 . Ich efekt to nie tylko nowa świadomość różnorodności wewnątrz ruchu, ale także zmiana paradygmatu: przejście do perspektywy intersekcjonalnej, w której pyta się, jak gender, klasa i etniczność wzajemnie na siebie oddziaływają w prawie, kulturze, historii czy polityce ${ }^{10}$. Skoro tak gruntownie udowodniono, że członkinie rozmaitych mniejszości rasowych i etnicznych obecne były w ruchu od początku (choć może nie tam, gdzie szukały ich potem mainstreamowe historyczki), skoro obalono pokutujące długo przekonanie, że druga fala była po prostu ruchem „białych kobiet z klasy średniej”, skoro splot rasa/etniczność/gender jest w centrum zainteresowania badaczy i badaczek historii ruchu kobiecego - to czy nie należałoby poświęcić nieco uwagi faktowi, że znaczną część owych „białych kobiet z klasy średniej" stanowiły właśnie Żydówki?

Podejmując ten temat, ryzykujemy jednak, że nasza perspektywa będzie perspektywą ahistoryczną, spojrzeniem z zewnątrz. Rzecz bowiem w tym, że chodzi o osoby, które nie chciały się swoją żydowską tożsamością zajmować. Betty Friedan pisała Mistykę kobiecości jako Amerykanka z białej klasy średniej, nie zaś jako amerykańska Żydówka. Nieszczęśliwe panie domu, które opisuje, to po prostu Amerykanki. Można, co prawda, zastanawiać się, jaki wpływ na retorykę tej książki - przede wszystkim na rozbudowane porównanie domu na przedmieściach do obozu koncentracyjnego - miało pochodzenie autorki ${ }^{11}$. Jak zauważa Joyce Antler, sfrustrowane udomo-

${ }^{8}$ Chodzi tu o wysyp książek monograficznych i antologii czarnego feminizmu z przełomu lat siedemdziesiątych i osiemdziesiątych oraz o nieco późniejszy przełom postkolonialny w feminizmie, czyli o prace takich autorek jak Audre Lorde, Angela Davis, Alice Walker, bell hooks, Barbara Smith, Gloria Anzaldúa, Hazel Carby, Linda Alcoff, Elizabeth V. Spelman, Chandra Mohanty, M. Jacqui Alexander czy Uma Narayan.

9 Do najciekawszych należy książka Benity Roth Separate Roads to Feminism: Black, Chicana, and White Feminist Movements in America's Second Wave (Cambridge University Press, Cambridge 2004). Por.: Winifred Breines, The Trouble Between Us. An Uneasy History of White and Black Women in the Feminist Movement (Oxford University Press, Oxford, New York 2006). Żadna z tych książek nie podejmuje jednak kwestii żydowskiej tożsamości znacznej części białych kobiet w ruchu.

${ }^{10}$ Za pracę, która zainicjowała ten przełom uważa się tekst Kimberlé Crenshaw, Demarginalizing the Intersection of Race and Sex, „University of Chicago Legal Forum” 1989, no. 140, s. 139-160.

${ }^{11}$ Moim zdaniem u Friedan analogia ta jest zdumiewająco wyprana z odniesień do korzeni samej autorki, a nawet do Żydów jako ofiar nazizmu; pełni ona w książce funkcję tropu 
wieniem bohaterki są uderzająco podobne do portretu Miriam Goldman, matki Friedan, jaki znajdujemy w jej tekstach wspomnieniowych, a także do postaci kobiecych z powieści Philipa Rotha czy Hermana Wouka ${ }^{12}$. Jest to jednak lektura podejrzliwa i demaskatorska; czytanie wbrew zamysłom autorki. Podobnie będzie z poszukiwaniem śladów żydowskiej tożsamości w tekstach radykalnych feministek takich jak Naomi Weisstein, Robin Morgan czy Meredith Tax.

Daniela Horowitza „spis Żydówek z drugiej fali feminizmu” przeczytałam w osłupieniu, zastanawiając się przez moment, które ze znanych mi białych feministek tego pokolenia nie były Żydówkami. W gruncie rzeczy nie był to jednak szok wynikający z konfrontacji z nową wiedzą, ale raczej szok rozpoznania. Wszystkie nazwiska na liście były mi dobrze znane; wiele z tych kobiet poznałam osobiście. Co więcej, od lat mam świadomość żydowskich korzeni wielu z nich. Ale nie tylu na raz, nie w takim zestawieniu. Przeczytałam zatem coś, co od dawna wiedziałam i czego zarazem nie wiedziałam, a może raczej nie dopuszczałam do świadomości. Mechanizm obronny uruchomił się natychmiast: przecież to nie miało żadnego związku z ich światopoglądem, pomyślałam; nie mamy prawa o tym mówić, skoro żadna z tych kobiet nie funkcjonowała publicznie jako Żydówka. No, może oprócz Grace Paley, znanej przecież żydowskiej pisarki starszego pokolenia, aktywnej jeszcze przed feministycznym przełomem. I jeszcze oprócz Letty Cottin Pogrebin, współzałożycielki magazynu „Ms.” Jej feministyczne przebudzenie miało jakoby miejsce, gdy odmówiono jej prawa do odmówienia kadiszu po śmierci matki, bo w minjanie nie ma miejsca dla kobiet, zaś przebudzenie żydowsko-feministyczne - po antysemickich incydentach podczas Światowych Konferencji ONZ ws. Kobiet (Meksyk, 1975; Kopenhaga, 1980) ${ }^{13}$. Zaczęły mi przychodzić do głowy kolejne wyjątki od rzekomej reguły nieważności lub czysto prywatnego wymiaru żydowskich korzeni feministek: Susan Gubar wydała niedawno Poetry after Auschwitz (2006) - pracę o Zagładzie, poezji i pamięci; Judith Butler w kontrowersyjnej książce Parting Ways (2013)

uniwersalistycznego - chodzi w niej o mechanizm uwewnętrznienia opresji, a nie o Żydów. O zimnowojennym kontekście tej analogii i jej asymilacyjnej funkcji piszę obszernie w tekście: „But this was not Nazi Germany. This was America.” Revisiting the Concentration Camp Analogy in Betty Friedan's „Feminine Mystique”, [w:] eds. Tomasz Basiuk, Sylwia Kuźma-Markowska, Krystyna Mazur, The American Uses of History. Essays on Public Memory, Peter Lang, Frankfurt am Main 2011, s. 267-280.

${ }_{12}$ Zob.: Joyce Antler, The Journey Home..., op. cit., s. 266.

${ }^{13}$ Ibidem, s. 284. W 1982 Letty Cottin Pogrebin wywołała burzę na łamach „Ms.” tekstem o antysemityzmie w ruchu kobiecym. O zdarzeniach podczas obu ONZ-owskich konferencji kobiecych i o reakcjach amerykańskich feministek szczegółowo pisze Gil Troy, When Feminists were Zionists (dostępne przez: http://www.tabletmag.com/jewish-arts-and-culture/ books/126348/when-feminists-were-zionists [08.03.2013]). 
krytykuje Izrael właśnie jako Żydówka; Friedan w swoich wspomnieniach Life So Far (2000) nie tylko wielokrotnie przywołuje doświadczenie antysemityzmu jako impuls, który uczynił ją wrażliwą na niesprawiedliwość, ale też raz po raz powtarza, że przez całe życie czuła się Żydówką ${ }^{14}$. Czy zatem mówimy o wyjątkach, czy o regule?

Mój szok i opór wzbudziło - i w jakimś stopniu nadal budzi - nie tyle odkrycie faktu żydowskich korzeni wielu działaczek i intelektualistek, co raczej nadanie temu faktowi ram ogólniejszego historycznego zjawiska. Powiedzmy sobie otwarcie: listy Żydów nie budzą dobrych skojarzeń. Nie budzą ich zwłaszcza, ale przecież nie tylko, w Polsce. W Stanach Zjednoczonych taka demaskatorska lista może wszak przywoływać skojarzenia z makkartyzmem. Czy zatem należy skreślić Horowitza jako mimo wszystko antysemitę? I czy amerykański antysemityzm jest porównywalny z polskim? Kluczowe w tym wszystkim jest jednak pytanie o perspektywę badawczą. Co począc $\mathrm{z}$ faktem, że w interesującym nas okresie, czyli pod koniec lat sześćdziesiątych, w ruchu kobiecym o tym się nie mówiło? Podobnie zresztą jak wcześniej w ruchu praw obywatelskich czy w protestach przeciwko wojnie w Wietnamie. W latach sześćdziesiątych polityczne znaczenie miała przynależność rasowa - stanowiła bowiem przedmiot politycznych zmagań Pochodzenie białych uczestników tych ruchów takiego znaczenia nie miało. Żydówki funkcjonowały w ruchu kobiecym po prostu jako kobiety białe, co zresztą miało kapitalne znaczenie dla ich życiorysów, począwszy od udziału w ruchu praw obywatelskich (w którym, podobnie jak inne białe dziewczyny, często ulegały fascynacji czarną kobiecością), poprzez głębokie zranienie, gdy ruch Black Power wyprosił białych, po częste wykorzystywanie analogii między czarnym a kobietą w tekstach feministycznych ${ }^{15}$. Połączenie perspektywy feministycznej i żydowskiej tożsamości następowało zwykle dopiero po kilku dekadach, jako pewna rama interpretacyjna nałożona na wcześniejsze doświadczenie. Oto jak ujęła to po latach Paula Doress, jedna z założycielek grupy Boston Women's Health Book Collective: „W ruchu praw obywatelskich i ruchu feministycznym identyfikowaliśmy się jako uniwersaliści. Obawialiśmy się zobaczyć, że zbytnio nas motywują nasze odrębności. Nie

${ }^{14}$ Betty Friedan, Life So Far. A Memoir, Simon and Schuster, New York 2001, s. 36-37, 308-309. Por.: Betty Friedan, It Changed My Life, Random House, New York 1976, s. 6.

${ }_{15} \mathrm{Na}$ temat złożonych relacji między rodzącym się białym feminizmem a ruchem na rzecz praw obywatelskich, między innymi właśnie fascynacji białych dziewcząt czarnymi „mamami”, zob.: Sara Evans, Personal Politics. The Roots of Women's Liberation in the Civil Rights Movement and the New Left, Random House, New York 1979. Por.: Agnieszka Graff, Więcej niż kontekst - kwestia rasowa a feminizm w Stanach Zjednoczonych, [w:] red. Małgorzata Radkiewicz, Gender: Konteksty, Rabid, Kraków 2004, s. 53-70. 
byłoby w porządku, gdybyśmy powiedzieli o sobie, że jesteśmy żydowskimi radykałami. Ale przecież właśnie nimi byliśmy"16.

Czy między ideologicznym i/lub organizacyjnym kształtem ówczesnego feminizmu a żydowską tożsamością wielu jego twórczyń jest jakiś istotny związek? Czy ówczesne milczenie na temat „odrębności” należy uznać za wiążące? Zanim zajmę się każdym z tych pytań, a przede wszystkim złożonymi źródłami owego milczenia, muszę przyjrzeć się nieco bliżej własnej wiedzy-niewiedzy. Dla całej sprawy kluczowy jest bowiem mechanizm wyparcia i przemilczenia.

\section{Kwestia żydowska? To nie mój temat}

W gruncie rzeczy o żydowskich korzeniach licznych - „nieproporcjonalnie” licznych, jak pisze Daniel Horowitz - feministek wiedziałam od dawna. Świadomość tę uparcie jednak spychałam do strefy rzeczy nieistotnych, bo, powiedzmy to sobie otwarcie: potencjalnie niebezpiecznych. Czytając pod koniec lat dziewięćdziesiątych Mistykę kobiecości, nie mogłam przecież nie wiedzieć, że Betty Friedan (z domu Goldstein) miała żydowskie korzenie. Czytając kilka lat później Dialectic of Sex Shulamith Firestone, od razu rozpoznałam imię autorki nie tylko z Pieśni nad Pieśniami (Sulamitka to przecież żona króla Salomona), ale także dlatego, że studiując w Stanach znałam osobiście pewną młodą Żydówkę imieniem Shuli i często rozmawiałam z nią o tym, co dla mnie i dla niej znaczą nasze żydowskie korzenie (dla niej bardzo wiele, dla mnie - jak wówczas sądziłam - nic). Wiedziałam też, głównie z wierszy, o żydowskich korzeniach jednej z kluczowych dla mnie autorek drugofalowej literatury - Adrienne Rich. Zastanowiło mnie jednak, że w najbardziej osobistym fragmencie Of Woman Born, jej wspaniałej książki o macierzyństwie, tam gdzie pisze o autorytarnym ojcu i podporządkowanej mu, głęboko tym upokorzonej matce, kwestia żydowskiej tożsamości ojca pojawia się tylko marginalnie, od razu uzupełniona o informację, że był on Południowcem i sugestię, że zapewne stąd się wziął jego dominujący stosunek do kobiet ${ }^{17}$.

Kolejny etap mojej wiedzy-niewiedzy to jesień 2004 roku, gdy podczas pobytu na stypendium w Nowym Jorku robiłam wywiady z przedstawicielkami (a właściwie weterankami) ruchu wyzwolenia kobiet. Wiedziałam, że większość moich rozmówczyń to Żydówki, ale nie zastanawiało mnie to szczególnie. Jeśli przedtem nie wiedziałam o żydowskich korzeniach Susan Brownmiller (autorki słynnego traktatu o historii gwałtu, Against Our Will i pięknej wspomnieniowej książki o ruchu wyzwolenia kobiet In

${ }^{16}$ Joyce Antler, The Journey Home..., op. cit., s. 283.

17 Adrienne Rich, Of Woman Born, Norton, New York 1976, s. 220. 
Our Time), to po wizycie w jej mieszkaniu w Greenwich Village i krótkim spojrzeniu na zestaw książek na jej półkach nie miałam już wątpliwości. Podobnie było z pisarką Alix Kates Shulman (autorką między innymi feministycznej powieści łotrzykowskiej Memoirs of an Ex-Prom Queen oraz ważnego dokumentu drugiej fali The Marriage Agreement). Oczywistością były też dla mnie żydowskie korzenie Ellen Willis (autorki między innymi ważnej diagnozy przyczyn deradykalizacji ruchu kobiecego), Phyllis Chesler (tej od Women and Madness), Vivian Gornick (autorki lirycznych tekstów „przebudzeniowych”, między innymi mojego ulubionego The Next Moment in History is Ours) czy Meredith Tax (której esej A Woman and Her Mind o doświadczeniu seksizmu i tożsamości kobiecej jako strukturze zbliżonej do schizofrenii był jednym z kluczowych manifestów ruchu). Domyślałam się też, że gościły mnie w swoich domach w dużej mierze dlatego, że zostałam im polecona jako Żydówka z Polski przez moją mentorkę a ich „siostrę” w radykalnym feminizmie - Ann Snitow. Wiedziałam też, rzecz jasna, że to żydowskie korzenie skierowały samą Ann do Polski jeszcze w latach dziewięćdziesiątych XX wieku.

Czy podczas wywiadów rozmawiałyśmy o tych sprawach? Tak, ale zawsze w oderwaniu od feminizmu. Kilkakrotnie musiałam odpowiadać na sakramentalne pytania ,jak możesz mieszkać w Polsce?” i „opowiedz nam o polskim antysemityzmie". Chesler w trakcie wywiadu jakby w ogóle nie interesowała się feminizmem - wciąż wracała do problemu konfliktu izraelsko-palestyńskiego, swojej tezy o antysemityzmie współczesnej amerykańskiej lewicy i swojego wielkiego żalu do feministek, które nie chciały wspierać Izraela i potępić świata muzułmańskiego. Rzecz jednak w tym, że mnie kwestia żydowska nie interesowała wcale. Usilnie starałam się odwrócić uwagę moich rozmówczyń od tych tematów. Pytałam je o młodzieńczą aktywność w ruchu praw obywatelskich, o Nową Lewicę, o przygodę z radykalnym feminizmem. Interesowało mnie, jak to było być młodą kobietą, która w 1967 lub 1968 roku odkrywa dla siebie feminizm, nie zaś, jak to było być wtedy młodą Żydówką.

Żadna z moich rozmówczyń nie była religijna, reprezentowały środowisko lewicujących świeckich Żydów z pokolenia baby boom. Rozumieli oni swoją tożsamość etniczną jako pewną ideologiczną i kulturową (ale już niekoniecznie religijną) schedę po tradycyjnych, choć związanych z ruchem socjalistycznym pradziadkach lub dziadkach, imigrantach z Europy Wschodniej, i po zbuntowanych wobec nich zasymilowanych rodzicach, wśród których wielu było z kolei członkami lub sympatykami partii komunistycznej w latach trzydziestych i czterdziestych (by w latach powojennych, mniej lub bardziej skrupulatnie, tuszować ten epizod w swoim życiorysie). Jak pisze antropolożka Karen Brodkin, z wielu modeli żydowskiej tożsamości i wielu 
gatunków asymilacyjnej ambiwalencji wyłania się współcześnie pewien wspólny rys: być Żydem to wyznawać pewien system wartości i znaczeń, które urealniają się w postaci działań na rzecz sprawiedliwości społecznej ${ }^{18}$.

Fakt, że odwiedzałam w ogromnej większości mieszkania żydowskich intelektualistek starszego pokolenia, nie stanowił tematu rozmowy. Zdarzało się jednak, że wprawiał mnie w pewną konfuzję. O Vivian Gornick pomyślałam, że jest trochę jak babcia, której nigdy nie miałam. Wiedziałam, że chodzi tu o wspólnotę kulturową, żydowską, a nie tylko feministyczną. Wspólne było poczucie humoru, sposób prowadzenia rozmowy, ironiczne formy okazywania sympatii. Na koniec spytałam ją, czy feminizm wiązał się z poczuciem rozczarowania amerykańską demokracją. W odpowiedzi usłyszałam:

Muszę ci powiedzieć, że to właśnie feminizm zrobił ze mnie Amerykankę. Jestem dzieckiem lewicowców, imigrantów, Żydów, członków klasy robotniczej - outsiderów pod każdym względem. Zawsze kiedy krytykowaliśmy Amerykę, lubiliśmy mówić, że to my jesteśmy prawdziwymi Amerykanami. Ale nie wierzyliśmy w to ani przez sekundę. Ani ja, ani moi rodzice nie czuliśmy się Amerykanami. Dopiero feminizm nagle zrobił ze mnie Amerykankę. Nagle poczułam, jak wzbiera we mnie obietnica demokracji i sens złamanych obietnic Republiki. To stało się dla mnie realne, stało się czymś, o co mogę walczyć. Poczułam, że mam prawo uznać się za członkinię tej wspólnoty politycznej. Gdy domagałam się swoich praw jako kobieta w Ameryce, w amerykańskiej Republice, czułam, że domagam się czegoś, co mi się należy, czegoś co jest mi przyrodzone ${ }^{19}$.

Gdy tego słuchałam, przyszło mi do głowy, że akces do ruchu kobiecego - tak jak trzy dekady wcześniej masowy akces do Frontu Ludowego - mógł mieć dla amerykańskich Żydówek wymiar asymilacyjny i że chodzi tu o konstruowanie białej tożsamości, bo Afroamerykanki i Latynoski takiej opcji nie miały. Pomyślałam, że jest to jakoś ciekawe. A jednak podjęłam mniej lub bardziej świadomą decyzję, by żydowskimi korzeniami moich bohaterek się nie zajmować. W wypowiedzi Gornick zainteresował mnie przede wszystkim patriotyzm. Fascynowała mnie amerykańskość amerykańskiego feminizmu: jego nieustanne odwołania do „amerykańskiej demokracji”, „amerykańskiego marzenia” czy „amerykańskiej obietnicy”, jego głębokie korzenie w indywidualizmie i etyce protestanckiej, jego złożone i często bolesne uwikłanie w problematykę rasową. Trzymając kurs na Amerykę jako pewien projekt polityczny i amerykańskość jako poczucie, że się ten projekt współtworzy, konteksty żydowskie uważałam po prostu za nierelewantne.

${ }^{18}$ Karen Brodkin, How Jews Became White Folks and What that Says about Race in America, Rutgers University Press, New Brunswick 2000, s. 172.

${ }_{19}$ Wywiad z Vivian Gornick przeprowadzony przez Agnieszkę Graff, Nowy Jork, listopad 2004, nagranie w archiwum autorki. 
Dziś wydaje mi się to niesłychanie naiwne, bo historia asymilacji amerykańskich Żydów, historia definicji i granic przynależności rasowej i historia amerykańskiej lewicy są ze sobą ściśle związane. Feminizm jest dla tej opowieści istotny, bo nie da się też zrozumieć powojennej asymilacji Żydów po II wojnie światowej, nie dostrzegając genderowego wymiaru tego procesu. Ale wtedy tego nie wiedziałam. Szukałam sedna feminizmu i sedna Ameryki, a kwestia żydowska zdawała się nie mieć z tym nic wspólnego.

\section{Nie jestem Żydem, bo nie chcę?}

Drugi powód mojej wiedzy-niewiedzy jest bardziej osobisty. Mój opór będzie zrozumiały dla każdego, kto otarł się o polski antysemityzm i wie, jak ważną rolę ogrywa w nim stereotyp żydokomuny. Jestem polską feministką o żydowskich korzeniach i wolałam tych dwóch faktów - mojego pochodzenia i moich poglądów - publicznie nie kojarzyć. Odblokował mnie pewien zbieg okoliczności. Mniej więcej w tym samym czasie, latem 2012 roku, przygotowywałam wstęp do polskiego wydania Mistyki kobiecości i śledziłam burzliwą debatę na łamach świątecznego wydania „Gazety Wyborczej” wokół Żydokomuny Pawła Śpiewaka. Największe wrażenie wywarł na mnie oskarżycielski tekst wybitnej antropolożki Joanny Tokarskiej-Bakir pt. Żydzi czerwoni i czarni ${ }^{20}$. Autorka bezlitośnie rozprawia się z pracą Śpiewaka, zarzucając mu nie tylko metodologiczne bałaganiarstwo, historyczne nieścisłości i błędy, ale także rasizm i antysemityzm. Żydokomuna to antysemicki stereotyp, służący usprawiedliwianiu przemocy i nienawiści, a Śpiewak - jak pokazuje autorka - podejmuje go w sposób metodologicznie i etycznie nie do przyjęcia: analiza stereotypu płynnie łączy się u niego $\mathrm{z}$ analizą zjawisk historycznych (uwikłania polskich Żydów jako pewnej zbiorowości w komunizm i odpowiedzialność poszczególnych polskich Żydów za konkretne zbrodnie stalinizmu). Dryfując swobodnie między uprzedzeniami a faktami historycznymi, książka przyczynia się do umocnienia tych pierwszych, umacnia polski antysemityzm. Służy to, zdaniem autorki, politycznemu uwiarygodnieniu samego autora jako polskiego Żyda, a zarazem konserwatysty. Atak dotyczy też sposobu, w jaki autor używa kategorii „Żyd”. Otóż zdaniem Tokarskiej-Bakir nadużyciem jest stosowanie tego określenia wobec ludzi, którzy od żydowskiej tożsamości świadomie i celowo odeszli, zostając komunistami (czyli nie tylko odchodząc od jakiejkolwiek religii, ale także przyswajając sobie ideę internacjonalizmu, która unieważnia etniczność).

${ }^{20}$ Joanna Tokarska-Bakir, Żydzi czerwoni i czarni, „Gazeta Wyborcza” 21-22 lipca 2012, pełna wersja tekstu dostępna przez: http://www.archiwumetnograficzne.edu.pl/ readarticle.php?article_id=123 (20.03.2013). 
Pierwsza część tej argumentacji jest dla mnie przekonująca. Zajmowanie się kategorią żydokomuna we współczesnej Polsce to działalność wielce ryzykowna etycznie i politycznie, należy mieć tego ryzyka świadomość, a już uczynienie z tego słowa tytułu książki zakrawa na prowokację. Lektura książki Pawła Śpiewaka i kolejnych krytycznych recenzji utwierdziła mnie zresztą w przekonaniu, że Tokarska-Bakir miała rację co do meritum: niezależnie od intencji, Śpiewak wyrządził swoją książką więcej szkody niż pożytku. Nic dziwnego, że Żydokomuna świetnie się sprzedaje w środowisku skrajnej prawicy. Natomiast drugi człon rozumowania Tokarskiej-Bakir wzbudził moje wątpliwości. Z tekstu wynika, że solidnej i uczciwej książki o roli Żydów w historii komunizmu Polsce (albo inaczej - o przygodzie polskich Żydów z komunizmem) nie da się napisać niejako z definicji. Żyd-komunista to nie kategoria badawcza, lecz oksymoron, bo zostając komunistą, odrzuca się zarówno religię, jak i etniczność, przestaje się więc być Żydem. Ciągłość, której szuka Śpiewak, po prostu nie istnieje.

Czy jednak istotnie tak jest? Czy tożsamość etniczna to kwesta indywidualnych wyborów, a każdy, kto twierdzi inaczej, jest rasistą? Udając się w gości do kogoś, kto ma na nazwisko Goldstein lub Sicherman, ale twierdzi, że nie uważa się za Żyda, bo albo przeszedł na katolicyzm, albo wychował się na Mickiewiczu, albo jest komunistą i w ogóle nie wierzy w narody, mam obowiązek szanować tę autodefinicję. Jednak pisząc biografię tegoż Goldsteina lub Sichermana, miałabym już obowiązek uwzględnić w swojej narracji żydowskie korzenie mojego bohatera. Z punktu widzenia refleksji historycznej tożsamość etniczna nie jest przecież prostą pochodną jednostkowego wyboru. Jest uwikłana w kontekst, w którym ludzie bywają definiowani na różne sposoby, często wbrew własnej woli, a następnie na te zewnętrzne definicje reagują. Wreszcie, co szczególnie ważne w przypadku naszych Żydówek-feministek, stosunek jednostki do własnych korzeni może się wielokrotnie zmieniać.

Kilka dni po lekturze tekstu, w którym Joanna Tokarska-Bakir oskarża Pawła Śpiewaka o rasizm i polityczny koniunkturalizm, trafiłam na tekst Daniela Horowitza o Betty Friedan jako Żydówce. Wertując antologię, w której został opublikowany, znalazłam też - i z fascynacją pochłonęłam - tekst Joyce Antler o Żydówkach w radykalnym nurcie feminizmu drugiej fali $^{21}$. Ten właśnie tekstowy zbieg okoliczności spowodował, że poczułam się

${ }^{21}$ Joyce Antler, „We Were Ready to Turn the World Upside Down”. Radical Feminism and Jewish Women, [w:] eds. Hasia R. Diner, Shira Kohn, Rachel Karson, A Jewish Feminine Mystique? Jewish Women in Postwar America, Rutgers University Press, New Brunswick 2010, s. 210-234. 
gotowa do rozmowy nie tylko o żydowskich korzeniach feministek, ale też o żydofeminie - o pewnym zbiorze pytań, lęków i przemilczeń dotyczących tych korzeni i ich znaczenia dla feminizmu.

\section{Żyd, czyli biały}

Teksty Horowitza i Antler uświadomiły mi, że temat ten ma w Stanach swoją historię, widoczną w życiorysach wielu konkretnych kobiet. W zależności od politycznego kontekstu i atmosfery epoki na przemian pojawia się możność i niemożność rozmowy, ważność i nieważność (lub potrzeba unieważnienia) żydowskiego pochodzenia. Ogromny wpływ na przemilczenia Friedan ma oczywiście makkartyzm, bo amerykański antykomunizm podszyty był antysemityzmem. Natomiast dla młodszych kobiet kapitalne znaczenie ma fakt, że narodziny radykalnego feminizmu zbiegły się w czasie z wojną arabsko-izrelską 1967 roku. Był to początek podziałów wśród amerykańskich Żydów, a także sporów na lewicy i wewnątrz ruchu kobiecego. Efekt był taki, że o tym, czyli o własnym żydowskim pochodzeniu, w ruchu kobiecym raczej się nie mówiło, z obawy, że naruszy to wciąż jeszcze kruche, bo bardzo świeże „siostrzane” więzi.

Warto pamiętać, że obecne było także napięcie między tożsamością żydowską a feminizmem jako takim. Feminizm zawsze jest buntem przeciw tradycji narodowej i religijnej - w przypadku Żydówek było oczywiście podobnie. Rzecz jednak w tym, że amerykańsko-żydowska tożsamość była wówczas tożsamością w trakcie głębokich przemian. W powojennej Ameryce Żydzi przeszli na drugą stronę rasowych podziałów: przestali być mniejszością rasową i stali się najpierw modelową mniejszością etniczną (często opisywaną w ówczesnej socjologii w kontraście z mniejszością czarną), by wreszcie stać się po prostu białymi Amerykanami. W latach siedemdziesiątych zaczęto się wręcz obawiać, że Żydzi w USA znikają jako mniejszość etniczna i po prostu wtapiają się w mainstream ${ }^{22}$. Brodkin określa ten proces mianem „etniczno-rasowej re-kategoryzacji” (ethnoracial reassignment) i pokazuje, że „wybieleniu” Żydów towarzyszyło ogromne napięcie, a także układające się w pewien wzór przemilczenia i tożsamościowe projekcje. Ówcześni wielcy żydowscy pisarze (tacy jak Philip Roth, Saul Bellow, Norman Mailer) i sławni nowojorscy intelektualiści (Lionel Trilling, Irving Howe, Norman Podhoretz, Daniel Bell czy Nathan Glazer) nadawali ton kulturze amerykańskiej i budowali liberalny konsensus, funkcjonując jako

${ }^{22}$ O skali asymilacji świadczy skłonność do zawierania mieszanych małżeństw. Jak podaje Brodkin, w 1957 roku zaledwie 3,5 proc. Żydów zawierało małżeństwa poza własną społecznością, zaś pod koniec lat osiemdziesiątych takie związki stanowiły już ponad połowę małżeństw. Por.: Karen Brodkin, op. cit., s. 159. 
pisarze i intelektualiści amerykańscy. Z rzadka tylko przypominali swoje żydowskie korzenie, zwykle po to, by przywołać uniwersalistyczny wymiar (przez odwołania do Zagłady) lub porównać żydowską kulturę do kultury Afroamerykanów. Porównania te wypadały na korzyść Żydów w pracach socjologicznych Nathana Glazera, zaś u Normana Mailera, jednego z ojców kontrkultury, pojawiał się wątek podziwu dla autentyzmu czarnej kultury i mocy czarnej męskości (najsłynniejszym zapisem tych fantazji jest esej The White Negro z 1955 roku), ale w obu przypadkach kontrast, jaki konstruowano między Żydami a Czarnymi, był bardzo wyrazisty.

Feministki drugiej fali należały zatem do pokolenia - a właściwie dwóch pokoleń - amerykańskich Żydów, których tożsamość etniczna podlegała bardzo silnym i złożonym, a zarazem bardzo ambiwalentnie przeżywanym zmianom. Brodkin poświęca wiele uwagi właśnie kwestii rasy, sugerując, że konsekwentne budowanie kontrastu między Żydami i Afroamerykanami było kluczem do konstruowania samych siebie jako białych, wskazuje jednak także, że proces asymilacji miał istotny wymiar genderowy. Lata powojenne to przede wszystkim czas wielkiego awansu żydowskich mężczyzn. Asymilacja polegała z jednej strony na przyjęciu anglosaskiego wzorca męskości, z drugiej zaś - na wyprojektowaniu na kobiety niepokoju i ambiwalencji związanych z procesem asymilacji. Efektem były dwa silnie mizoginiczne stereotypy projekcyjne wszechobecne w powojennej żydowskiej literaturze i kulturze popularnej: wizerunek przytłaczająco opiekuńczej i dominującej (wręcz kastrującej) żydowskiej matki (kluczowy między innymi dla Kompleksu Portnoy'a Philipa Rotha), a począwszy od lat siedemdziesiątych stereotyp żydowskiej amerykańskiej księżniczki (Jewish American Princess - JAP), uosobienia materializmu i burżuazyjnych aspiracji. Najciekawsza w tych stereotypach jest ich dwoistość. Z jednej strony są one bardzo żydowskie, bo zawarta w nich agresja wobec kobiet pozwala na bezpieczną artykulację związanych z asymilacją tęsknot i lęków: żydowska matka ucieleśnia tradycyjną żydowską wspólnotowość, siłę i miłość; żydowska księżniczka to odzwierciedlenie tego, co najbardziej odrażające, a zarazem pociągające w zindywidualizowanej białej kulturze konsumenckiej: jej intelektualnej pustki, nienasycenia, narcyzmu. Jednocześnie jednak oba te mizoginiczne stereotypy są bardzo amerykańskie, świetnie pasują do szerszego nurtu kultury i zostały przez nią z latwością przyswojone. Dotyczy to zwłaszcza postaci kastrującej matki, podejrzanej na przykład o to, że wrabia wszystkich wokół w poczucie winy, a przez nadmiar czułości przyczynia się powstawania u chłopców skłonności homoseksualnych. Jak pisze Brodkin:

Żydzi oczywiście nie wynaleźli homofobii i oskarżania matek [mother bashing], zjawisk wszechobecnych w kulturze lat pięćdziesiątych - by się o tym przekonać wystarczy poczytać doktora Spocka - jednak stereotyp żydowskiej matki okazał się etnicznym 
darem świeżo wybielonych żydowskich mężczyzn dla tej szerszej patriarchalnej białej kultury. Żarty o żydowskich matkach podobały się wszystkim, zwłaszcza członkom innych białych mniejszości etnicznych, jako sposób na przyłączenie się do białego obyczaju dopiekania matkom. Nie trzeba było być Żydem by polubić żydowski wkład do amerykańskiej kultury. I nie trzeba było być Żydówką by zostać złośliwie opisaną jako Żydowska matka ${ }^{23}$.

Zrytualizowana w seksistowskich stereotypach i żartach mizoginia okazuje się więc jednocześnie ujściem dla żydowskich lęków i przepustką do białej Ameryki. Jest tym, co w Żydach najbardziej żydowskie i zarazem najbardziej amerykańskie. Istotną rolę w tym procesie odgrywa też matrofobia córek, która, jak zauważyła Adrienne Rich, jest w żydowskiej kulturze stosunkowo młodym zjawiskiem, związanym właśnie z asymilacją ${ }^{24}$. Dowcipy o JAP-ach i żydowskich matkach do dziś stanowią chleb powszedni amerykańskiej mizoginii i są odbierane nie jako przejaw antysemityzmu, lecz raczej zwykłego ogólnoamerykańskiego seksistowskiego humoru²5. Można zaryzykować tezę, że ceną za asymilację było przyzwolenie na szczególne napiętnowanie kobiet z własnej grupy etnicznej ${ }^{26}$.

Jaki to miało wpływ na porzucenie żydowskiej identyfikacji przez kobiety żydowskiego pochodzenia, które na przełomie lat sześćdziesiątych i siedemdziesiątych współtworzyły w Stanach feminizm? Czy fakt, że jako Żydówki uczestniczyły w tym genderowym rytuale asymilacyjnym, miał wpływ na ich akces do feminizmu i na kształt ówczesnej myśli feministycznej? Sądzę, że tak właśnie musiało być, choć świadomość - a wraz z nią potrzeba połączenia tożsamości feministycznej z żydowską w harmonijną całość - przyszła dopiero po latach. Pod koniec lat sześćdziesiątych ich bunt - feministyczny i uniwersalistyczny - był w dużej mierze buntem przeciw strategii asymilacyjnej, która w negocjacjach z kulturą dominującą spychała kobiety do roli bohaterek seksistowskich żartów.

\section{Żydówka, czyli typowa Amerykanka}

Z prac Antler można wywnioskować, że wiele życiorysów układa się w następujący wzór: porzucały swoje korzenie w okresie, gdy przeformułowywały swoją kobiecość (czyli w latach sześćdziesiątych), by potem do nich wrócić $\mathrm{i}$ - w wielu przypadkach - budować feminizm wewnątrz społeczności żydowskiej. Rzecz jasna zdarzają się jednostkowe odrębności i wariacje, rysuje się

${ }^{23}$ Ibidem, s. 169.

24 Adrienne Rich, op. cit., s. 238.

${ }^{25}$ Na przykład takie: „Co robi JAP na kolację? - Rezerwację”; „Ile trzeba żydowskich matek, by wkręcić żarówkę? - Oj, ty się już o mnie nie martw serdeńko, ja sobie posiedzę po ciemku".

${ }^{26}$ Karen Brodkin, op. cit., s. 172. 
jednak pewna wspólnota losów i przemilczeń, a także pewna interesująca różnica pokoleniowa. Jak zauważa Daniel Horowitz, urodzona w 1921 roku Betty Friedan zawsze prywatnie czuła się Żydówką, a decyzje, by publicznie o tym milczeć lub mówić, miały charakter strategiczny, w pełni świadomy. Podobnie rzecz się ma z jej rówieśnicami jak Letty Pogrebin czy Carolyn Heilbrun. Tymczasem, jak pokazuje Antler, w przypadku młodszych od Friedan o dwie dekady radykalnych feministek przemilczenia miały charakter bardziej emocjonalny, osobisty. Wydaje się, że ambiwalentny stosunek do własnych korzeni stanowił raczej istotny rys ich tożsamości niż aspekt świadomie kształtowanej strategii politycznej. Zresztą nic w tym dziwnego, bo w radykalnym feminizmie „prywatne” jest przecież zawsze „polityczne”.

Można też tropić źródła tej różnicy w kontekście historycznym. Dla pokolenia Friedan punktem odniesienia była II wojna światowa, uniwersalizowany w ówczesnym dyskursie publicznym Holocaust; dla młodszych od niej o pokolenie kobiet, formatywnym doświadczeniem był konflikt arabsko-izraelski, wobec którego trudno było się jednoznacznie określić, będąc jednocześnie członkiem radykalnej nowej lewicy i żydowskiej diaspory. Do przesilenia doszło w czerwcu 1975 roku, podczas Światowej Konferencji ONZ ds. Kobiet w Meksyku, gdzie wygwizdano żonę izraelskiego premiera, zachodnim feministkom dawano jasno do zrozumienia, że są burżujkami, stojącej na czele amerykańskiej delegacji Betty Friedan poradzono życzliwie, by dla własnego bezpieczeństwa wyjechała z miasta, a wreszcie, zmieniając procedury głosowania, zapisano w deklaracji końcowej konferencji, że syjonizm to jedna $\mathrm{z}$ form rasizmu ${ }^{27}$. W kolejnych latach różne amerykańskie feministki pochodzenia żydowskiego zajmowały wobec tych kwestii różne stanowiska: Friedan jednoznacznie proizraelskie, a na przykład lewicowa Ellen Willis „anty-anty-syjonistyczne” - był to jednak dla wielu kobiet koniec milczenia o swoim żydowskim pochodzeniu, a zarazem koniec pewnej fazy feminizmu. Jak mi wyjaśniła jedna z moich rozmówczyń, w Meksyku skończył się sen o siostrzeństwie, a zaczęła prawdziwa polityka ${ }^{28}$.

Wróćmy jednak do Friedan. Jak pisze Daniel Horowitz, w dzieciństwie miała ona pełną jasność, że jest Żydówką, a w młodości często podejmowała refleksję (także publicznie) nad swoją tożsamością. Wychowała się w miasteczku Peoria w stanie Illinois, w rodzinie agnostyków, gdzie świętowano na równi Hanukę i Boże Narodzenie. Decydujący dla jej późniejszych przemyśleń o roli kobiet w amerykańskim społeczeństwie był konflikt z matką, który, jak wspomniałam, można interpretować jako konflikt specyficznie żydowski - tak właśnie czyta go Horowitz ${ }^{29}$. Udomowienie, władczość

${ }^{27}$ Gil Troy, op. cit.

${ }^{28}$ Prof. Carolyn Elliott, rozmowa z autorką w styczniu 2005.

29 Daniel Horowitz, Jewish Women..., op. cit., s. 235-236. 
i wynikająca z porzuconych ambicji głęboka frustracja były w tamtej epoce charakterystyczne nie tyle dla Amerykanek, co dla Żydówek z klasy średniej, które statystycznie rzecz biorąc były zamożniejsze, lepiej wykształcone, a zarazem bardziej podporządkowane mężom niż inne przedstawicielki tej grupy społecznej. Sama Friedan myślała jednak o udomowieniu matki jako o czymś typowym dla białej klasy średniej, zaś żydowskie korzenie oznaczały dla niej przede wszystkim alienację, status outsidera i wzmożoną wrażliwość na wszelkie uprzedzenia.

Podczas studiów w Smith College (1938-1942) żydowska tożsamość, przeżywana w odniesieniu do nazizmu, staje się tematem intelektualnych rozważań Friedan i pierwszych prób dziennikarskich. Po uzyskaniu dyplomu wygłasza w synagodze w rodzinnej Peorii mowę pt. „Affirming one's Jewishness" [Afirmując swoje żydowskie korzenie]. W latach 1943-1952 pisuje ostre lewicowe teksty w prasie związkowej, wiele uwagi poświęcając właśnie antysemityzmowi. W 1947 wychodzi za mąż za religijnego Żyda, Carla Friedana (ur. jako Friedman). Jeszcze w 1953 roku jej teksty ukazują się na łamach żydowskiego czasopisma popierającego partię komunistyczną. Cięcie następuje w drugiej połowie lat pięćdziesiątych, w epoce makkartyzmu. Friedan zaczyna budować swoją publiczną dziennikarską tożsamość jako „typowa amerykańska pani domu”. Prywatnie nigdy się nie wyrzeknie żydowskiej tożsamości. Dom, który stworzy z Carlem, nie będzie domem religijnym, ale pozostanie jednoznacznie żydowski: u Friedanów świętowało się Pessah jako opowieść o wyzwoleniu, a synom urządzono „ateistyczne bar micwy”. Jednak publicznie, pisząc Mistykę..., a potem budując liberalne skrzydło feminizmu, Friedan świadomie i bardzo starannie tuszuje - a może po prostu pomija - żydowski wątek swojego życiorysu, podobnie jak milczy o swojej młodzieńczej przygodzie z lewicą. Krótko mówiąc, w latach sześćdziesiątych odtwarzała model wypracowany po wojnie przez nowojorskich intelektualistów: była Amerykanką, a nie amerykańską Żydówką.

Na początku kolejnej dekady następuje zwrot: autorka Mistyki... otwarcie i publicznie wraca do swoich żydowskich korzeni. Za symboliczny przełom można uznać mowę, którą Friedan wygłosiła 26 sierpnia 1970 roku podczas kobiecego marszu Women's Strike for Equality w Nowym Jorku. Przywołała w niej poranną modlitwę swoich przodków, w której dziękowali Bogu, że nie są kobietami, po czym wyraziła nadzieję, że od dziś kobiety na całym świecie będą mu dziękować za to, że są kobietami. Joyce Antler uważa, że zwrot ku żydowskim korzeniom miał związek ze świadomością feministyczną, z wpisaną w nią potrzebą autentyzmu ${ }^{30}$. Zdaniem Daniela Horowitza istotne było raczej to, że dorastający wtedy synowie Friedan zaczęli być ciekawi rodzinnej

3o Joyce Antler, The Journey Home..., op. cit., s. 259. 
historii ${ }^{31}$. Zmiana ta niewątpliwie wpisuje się też w początek tzw. etnicznego renesansu w USA - zwrotu w dyskursie publicznym od asymilacji (melting pot) do wielokulturowości (salad bowl). Zasadnicze znaczenie mają również spory dotyczące stosunku do państwa Izrael, wobec których coraz trudniej utrzymać dystans. Na początku dekady Friedan odbywa dwie podróże do Izraela; w 1974 publicznie protestuje przeciw antysemickim wątkom przemówienia Yassera Arafata w ONZ; rok później, po antysemickich awanturach w Meksyku pisze pełen oburzenia artykuł; wreszcie, w listopadzie 1975 pojawia się niezapowiedziana na proteście przeciw antysyjonistycznej rezolucji Zgromadzenia Ogólnego ONZ (nr 3379). Przedstawia się zgromadzonym ,jako kobieta, jako Amerykanka, jako Żydówka” i oświadcza: „Całe życie walczę o sprawiedliwość, i aż do dziś nigdy nie uważałam się za syjonistkę"32.

Gdy w samym feminizmie w drugiej połowie lat siedemdziesiątych pojawia się podszyty antysemityzmem wizerunek judaizmu jako religii stojącej u źródeł patriarchatu, Betty Friedan protestuje, polemizuje, przy czym całkiem otwarcie wypowiada się jako Żydówka. W kolejnych latach staje się coraz bardziej konserwatywna i znów tożsamość żydowska jest tu nie bez znaczenia. W 1988 roku, udzielając żydowskiemu periodykowi wywiadu, mówi z szacunkiem o rodzinności, wspólnocie, społeczności. Horowitz podsumowuje te przemiany:

\begin{abstract}
Nie było takiego okresu, w którym Friedan nie myślałaby o sobie jako o Żydówce, nie zastanawiała się nad problemem antysemityzmu oraz nad tym, że jej oddanie kwestiom sprawiedliwości społecznej ma swoje źródła w fakcie, że była Żydówką czyli outsiderką. [...] Tym, co zmieniło się około 1970 roku, był zewnętrzny kontekst jej życia: publiczność stała się bardziej otwarta na te tematy, jej własne dzieci zaczęły dorastać, rozpowszechniła się moda na poszukiwanie korzeni, jej pozycja w ruchu stała się marginalna, a w Stanach rozkwitł żydowski feminizm ${ }^{33}$.
\end{abstract}

\title{
Lepiej nie zwracać uwagi
}

Jak wyglądało skrzyżowanie feminizmu i żydowskiej tożsamości u znacznie od Friedan młodszych feministek radykalnych? Na to pytanie odpowiada Joyce Antler. Logika przemilczeń i spóźnionej identyfikacji jest tu zdecydowanie bardziej zawikłana, między innymi dlatego, że mimo oburzenia antysemityzmem, stanowisko jednoznacznie proizraelskie było w tym środowisku nie do pomyślenia. W 2008 roku Antler przeprowadziła pogłębione wywiady z czterema weterankami ruchu urodzonymi w latach 1939-1946.

${ }^{31}$ Daniel Horowitz, Jewish Women..., op. cit., s. 240.

${ }^{2}$ Gil Troy, op. cit.

33 Ibidem, s. 242. 
Jej bohaterki - Naomi Weisstein, Amy Kesselman, Heather Booth i Vivian Rothstein - dorastały w komunizujących rodzinach żydowskich, należą więc do grupy określanej mianem red diaper babies. Ich matki, mimo silnych osobowości i radykalnie lewicowych poglądów, uległy presji „udomowienia” i po urodzeniu dzieci zrezygnowały z wcześniejszych aspiracji. Etos postępowych żydowskich rodzin sprawil, że późniejsze feministki były aktywne społecznie jeszcze w czasach licealnych, a podczas studiów zaangażowały się w ruch na rzecz praw obywatelskich i protesty przeciw wojnie w Wietnamie. Na tym etapie dochodziło do wyciszenia, unieważnienia żydowskich korzeni. Jak wyjaśnia Kesselman w rozmowie z Antler:

Nasza identyfikacja ze światem zewnętrznym, powstała w opozycji do wąskich (obronnych, nasyconych lękiem) horyzontów naszych rodziców, była buntownicza i postępowa [...] to był sprzeciw wobec etnicznych i religijnych podziałów w społeczeństwie. Po cóż miałybyśmy się identyfikować jako Żydówki, skoro naszym celem było budowanie wizji międzynarodowej, ponadnarodowej i ponadreligijnej solidarności? ${ }^{34}$

Poznały się jako aktywistki ruchu studenckiego, a ich feminizm zrodził się z burzliwych konfliktów z mężczyznami w tym ruchu i z rozmów, w których analizowały seksistowski rys tych rzekomo oddanych sprawie równości buntowników. W 1967 roku wspólnie tworzyły jedną z pierwszych w USA radykalnych grup feministycznych: Chicago Women's Liberation Union. Po latach opisały to wszystko w eseju Our Gang of Four (1989) ${ }^{35}$.

Każdy, kto zna ten tekst, będzie zdumiony łatwością, wręcz entuzjazmem, z jakim cztery przyjaciółki z Chicago podjęły temat swoich korzeni, gdy poprosiła je o to historyczka. W 2008 roku były w pełni gotowe do pogłębionej refleksji na temat wpływu tożsamości żydowskiej na swoje polityczne zaangażowanie, a także na temat możliwych przyczyn późniejszych przemilczeń. Co ciekawe, wątek izraelski w ogóle się tu nie pojawia; rozważania mają wymiar osobisty, a jeśli nawiązują do polityki, to chodzi wyłącznie o kwestię żydowskiej lewicowości. „Mimo iż pochodziłyśmy z rodzin Żydów zbuntowanych, żydowskie wartości były w naszym życiu wszechobecne", tłumaczy Naomi Weisstein, po czym dodaje z rozbrajającą szczerością: „ale nigdy o tym nie mówiłyśmy”. Dalej wyjaśnia, że milczenie wynikało z pragnienia, by nie powtórzyć historii przedwojennej lewicy, z nadziei, że uda się stworzyć ruch lewicowy nienaznaczony obcością, szerszy niż ten, w którym się wychowały

34 Joyce Antler, We Were Ready..., op. cit., s. 219.

35 Amy Kesselman, Heather Booth, Vivian Rothstein, Naomi Weisstein, Our Gang of Four: Friendship and Women's Liberation, [w:] eds. Rachel Du Plessis, Ann Snitow, The Feminist Memoir Project. Voices from Women's Liberation, Three Rivers Press, New York 1998, s. 25-53. 
jako red diaper babies. Stąd niepisana umowa, by nie zwracać niczyjej uwagi na „nieproporcjonalnie duży udział Żydów w Nowej Lewicy”36.

Kilka lat wcześniej te same kobiety wspólnie napisały Our Gang of Four obszerny esej, który wątek żydowski całkowicie pomija. A przecież redaktorki Feminist Memoir Project nie wymagały od nikogo autocenzury; ta piękna książka to miejsce osobistych zwierzeń, opowieści o trudnych historiach (m.in. napięciach wokół kwestii rasowej, a także o osobistych dramatach i konfliktach wewnątrz ruchu kobiecego), wydawałoby się: wymarzona przestrzeń do dywagacji o wspólnocie żydowskich losów czterech przyjaciółek z Chicago. Ich tekst jest barwny, pełen intymnych szczegółów, ale nie wspominają słowem o tym, że wszystkie były z pochodzenia Żydówkami. Nie tylko one o tym milczą - o znaczącej liczbie Żydówek w ruchu wyzwolenia kobiet nie pisał do tej pory nikt oprócz Antler i Horowitza. Niepisana umowa, by o tym nie mówić, przetrwała dziesiątki lat.

\section{Od żydowskości do uniwersalizmu - i z powrotem}

Zastanawiając się, jak coś może być zarazem ważne i nieważne, pamiętane i spychane w niepamięć, przypomniałam sobie cytowaną tu już odpowiedź Vivian Gornick na pytanie, czy pod koniec lat sześćdziesiątych była rozczarowana Ameryką: „Dopiero feminizm nagle zrobił ze mnie Amerykankę. Nagle poczułam, jak wzbiera we mnie obietnica demokracji i sens złamanych obietnic Republiki”. Niedawno wpadła mi w ręce wydana w 2005 roku książka Vivian Gornick pt. The Solitude of Self, poświęcona wybitnej amerykańskiej sufrażystce Elizabeth Cady Stanton. Jest to właściwie list miłosny do wielkiej poprzedniczki, matki założycielki amerykańskiego ruchu kobiecego, a zarazem pełna emocji pochwała buntowniczego ducha Ameryki. Feminizm jest na wskroś amerykański, powtarza Gornick, a w spuściźnie po Stanton fascynuje ją głównie indywidualizm, osobność, sposób w jaki solitude of self nawiązuje do Emersonowskiej self-reliance. Co ciekawe, w ostatnim passusie książki Gornick przywołuje wizytę w Nowym Jorku izraelskiego pisarza Davida Grossmana i jego nerwową próbę wyjaśnienia, dlaczego w Izraelu nie ma znaczącego ruchu pokojowego. Grossman miał powiedzieć: „Nie potrafimy znieść stanu alienacji wobec własnych rodziców". Na tej podstawie, poprzez przeciwstawienie między amerykańskim indywidualizmem a izraelskim kolektywizmem, Gornick buduje swoją wizję Ameryki oraz tezę o amerykańskości feminizmu. Robi to wszystko jako Amerykanka, unikając jednocześnie deklaracji, jeśli chodzi o jej własny stosunek do Izraela:

\footnotetext{
${ }^{36}$ Ibidem, s. 218.
} 


\begin{abstract}
W tym właśnie momencie lepiej zrozumiałam mój kraj. Ameryka nie powstała na bazie rodziny. W Ameryce etos autokreacji wytworzył dumną, szorstką, szczeniacką skłonność do zanurzania się w stanie pożytecznej samotności. W kraju takim jak Izrael tego rodzaju samotność sprawia, że ludzie rozpadają się na kawałki. Oto wielki paradoks: owa słynna amerykańska samotność, ze swoim credo o samowystarczalności, raz po raz stawała się źródłem siły dla wybuchów zbiorowego buntu. [...] Dlatego, wierzę w to głęboko, feminizm jest amerykański ${ }^{37}$.
\end{abstract}

Ten cytat oczywiście więcej mówi o stanie świadomości samej Gornick - lewicowej amerykańskiej Żydówki, weteranki drugiej fali feminizmu w jej specyficznym nowojorskim wydaniu - niż o Ameryce, czy nawet o amerykańskim feminizmie, który był i jest niesłychanie różnorodny i nie wywodzi się jedynie od Stanton. Rzecz jednak w tym, że taki właśnie - uniwersalistyczny, ekspresyjny, indywidualistyczny - był radykalny feminizm końca lat sześćdziesiątych, feminizm, który Gornick współtworzyła, uciekając od swoich żydowskich korzeni, i który po latach wspomina z egzaltacją jako na wskroś amerykański.

Paradoks polega moim zdaniem na tym, że pod koniec lat sześćdziesiątych tożsamość Żydówek-feministek była zarazem bardzo żydowska, nasycona idealistycznym przekazem wyniesionym z lewicowych domów i oparta na głębokiej potrzebie ucieczki od etnicznej identyfikacji. Było od czego uciekać: od tradycjonalizmu relacji męsko-damskich w żydowskich domach, od komplikacji jaką niosło posiadanie w latach pięćdziesiątych rodziców komunistów, od wyobcowania, które towarzyszyło Żydom w tej epoce, ale powoli zaczynało zanikać, od trudnych sporów o Izrael, a być może także od żydowskiej mizoginii, którą Brodkin opisuje jako dar złożony przez etniczną mniejszość białej kulturze. Ich ambiwalencja stanowiła jeden z nurtów ambiwalencji asymilujących się do białej Ameryki Żydów. To z niej wzięła się potrzeba milczenia, pragnienie, by w pełni zanurzyć się w atmosferze utopijnego uniwersalizmu, która napędzała ruchy kontrkulturowe lat sześćdziesiątych. Lewicowość, którą te kobiety współtworzyły, miała być nie żydowska, lecz ogólnoludzka, a w przypadku feminizmu - ogólnokobieca. Lewicowość musiała zostać zredefiniowana jako amerykańska. Akurat pod koniec lat sześćdziesiątych było to, bodaj po raz pierwszy w historii USA, naprawdę możliwe.

Powstała w tym procesie równościowa ideologia przesycona jest drapieżnym uniwersalizmem i indywidualizmem, a kluczowym postulatem nie jest równość ekonomiczna, lecz „autonomia” i ,autentyczność” jednostki, wyzwolenie od „alienacji”. Jest to ideologia na wskroś amerykańska, nawet wówczas, gdy wytacza najcięższe działa przeciw kapitalistycznej i patriarchalnej

37 Vivian Gornick, The Solitude of Self. Thinking about Elizabeth Cady Stanton, Farrar, Strauss and Giroux, New York 2005, s. 131. 
Ameryce. Intelektualne źródła tego krytycznego, ale zarazem amerykańskiego uniwersalizmu są rozmaite: postępowa tradycja chrześcijańskiego egzystencjalizmu spod znaku Reinholda Niebuhra i Paula Tillicha, w której zaczytywali się twórcy nowej lewicy, specyficznie przetworzony freudyzm, nurty ówczesnej psychologii, które legły u podstaw Ruchu Ludzkiego Potencjału - teksty Maslowa, a nieco później Lainga ${ }^{38}$. Warto jednak rozpatrzyć i taką możliwość, że do owego uniwersalizmu przyczynił się fakt, że ruchy społeczne tej epoki od samego początku współtworzyli Żydzi, którzy bardzo chcieli być po prostu Amerykanami. Dotyczyło to także Żydówek-feministek.

A może było odwrotnie? Może to one garnęły się do ruchu wyzwolenia kobiet, bo jawił się im jako uniwersalistyczny, wolny od dusznych i trudnych tożsamościowych uwikłań? Jak zwykle w procesach kulturowych trudno wskazać, co jest przyczyną, a co skutkiem. Jak zauważa Brodkin, uniwersalność ówczesnych żydowskich stereotypów genderowych wynikała stąd, że Żydzi nie tylko przyłączyli się do białej Ameryki, ale też pomogli tę biel skonstruowaćc ${ }^{39}$. Ambiwalentnie przeżywana tożsamość - tożsamość oparta na kontraście własnej grupy z Afroamerykanami, a następnie nie tyle ukrywana, co spychana w sferę tego, „o czym się nie mówi”, a potem znów odkrywana choć na innych zasadach - odcisnęła na tym ruchu, jego ideach i jego retoryce swoje piętno. Splot między gender a podlegającą „wybieleniu” żydowską etnicznością polegał na tym, że w latach pięćdziesiątych i sześćdziesiątych Żydzi projektowali swoje tożsamościowe lęki i aspiracje na dyskurs o płci. Mizoginia dla mężczyzn, akces do feminizmu dla kobiet - obie te strategie można odczytywać jako aspekty procesu asymilacji.

\section{BIBLIOGRAFIA}

Antler Joyce, „We Were Ready to Turn the World Upside Down”. Radical Feminism and Jewish Women, [w:] eds. Hasia R. Diner, Shira Kohn, Rachel Karson, A Jewish Feminine Mystique? Jewish Women in Postwar America, Rutgers University Press, New Brunswick 2010.

Antler Joyce, The Journey Home. How Jewish Women Shaped Modern America, Shocken Books, New York 1997.

${ }^{38}$ O wpływie myśli chrześcijańskiej na nową lewicę w USA ciekawie (także w odniesieniu do ruchu wyzwolenia kobiet) pisze Doug Rossinow w książce The Politics of Authenticity. Liberalism, Christianity and the New Left in America (Columbia University Press, New York 1998). Wpływ psychologii humanistycznej i Ruchu Ludzkiego Potencjału na drugą falę feminizmu błyskotliwie analizuje Jane Gerhard w Desiring Revolution. Second Wave Feminism and the Rewriting of American Sexual Thought 1920-1982 (Columbia University Press, New York 2001).

39 Karen Brodkin, op. cit., s. 171. 
Breines Winifred, The Trouble Between Us. An Uneasy History of White and Black Women in the Feminist Movement, Oxford University Press, Oxford, New York 2006.

Brodkin Karen, How Jews Became White Folks and What that Says about Race in America, Rutgers University Press, New Brunswick 2000.

Crenshaw Kimberlé, Demarginalizing the Intersection of Race and Sex, „University of Chicago Legal Forum" 1989, no. 140.

Davis Flora, Moving the Mountain. The Women's Movement in America since 1960, University of Illinois Press, Urbana 1999.

Evans Sara, Personal Politics. The Roots of Women's Liberation in the Civil Rights Movement and the New Left, Random House, New York 1979.

Evans Sara, Tidal Wave. How Women Changed America at Century's End, The Free Press, New York 2003.

Friedan Betty, It Changed My Life, Random House, New York 1976.

Friedan Betty, Life So Far. A Memoir, Simon and Schuster, New York 2001

Gerhard Jane, Desiring Revolution. Second Wave Feminism and the Rewriting of American Sexual Thought 1920-1982, Columbia University Press, New York 2001.

Gornick Vivian, The Solitude of Self. Thinking about Elizabeth Cady Stanton, Farrar, Strauss and Giroux, New York 2005.

Graff Agnieszka, „But this was not Nazi Germany. This was America.” Revisiting the Concentration Camp Analogy in Betty Friedan's „Feminine Mystique”, [w:] eds. Tomasz Basiuk, Sylwia Kuźma-Markowska, Krystyna Mazur, The American Uses of History. Essays on Public Memory, Peter Lang, Frankfurt am Main 2011.

Graff Agnieszka, Mistyka, mistyfikacja, lustracja, czyli kilka słów o „Feminine Mystique” Betty Friedan, „Res Publica Nowa” 2008, nr 4.

Graff Agnieszka, Więcej niż kontekst - kwestia rasowa a feminizm w Stanach Zjednoczonych, [w:] red. Małgorzata Radkiewicz, Gender: Konteksty, Rabid, Kraków 2004.

Horowitz Daniel, Betty Friedan and the Making of the Feminine Mystique, University of Massachusetts Press, Amherst 1998

Horowitz Daniel, Jewish Women Remaking American Feminism/Women Remaking American Judaism. Reflections on the Life of Betty Friedan, [w:] eds. Hasia R. Diner, Shira Kohn, Rachel Karson, A Jewish Feminine Mystique? Jewish Women in Postwar America, Rutgers University Press, New Brunswick 2010.

Kesselman Amy, Heather Booth, Vivian Rothstein, Naomi Weisstein, Our Gang of Four: Friendship and Women's Liberation, [w:] eds. Rachel Du Plessis, Ann Snitow, The Feminist Memoir Project. Voices from Women's Liberation, Three Rivers Press, New York 1998.

Mrozik Agnieszka, Akuszerki transformacji. Kobiety literatura i władza w Polsce po 1989 roku, Lupa Obscura, Warszawa 2012.

Rich Adrienne, Of Woman Born, Norton, New York 1976.

Rosen Ruth, The World Split Open: How the Modern Women's Movement Changed America, Viking, New York 2000.

Rossinow Doug, The Politics of Authenticity. Liberalism, Christianity and the New Left in America (Columbia University Press, New York 1998.

Roth Benita, Separate Roads to Feminism: Black, Chicana, and White Feminist Movements in America's Second Wave, Cambridge University Press, Cambridge 2004.

Tobias Sheila, Faces of Feminism. An Activist's Reflection on the Women's Movement, Westview Press, Boulder Co. 1997. 
Tokarska-Bakir Joanna, Żydzi czerwoni i czarni, „Gazeta Wyborcza” 21-22 lipca 2012, pełna wersja tekstu dostępna przez: http://www.archiwumetnograficzne.edu.pl/readarticle. php?article_id=123 (20.03.2013).

Troy Gil, When Feminists were Zionists; dostępne przez: http://www.tabletmag.com/ jewish-arts-and-culture/books/126348/when-feminists-were-zionists (08.03.2013).

Zawadzka Anna, „Żydokomuna”. Szkic do socjologicznej analizy źródet historycznych; dostępne przez: http://www.archiwumetnograficzne.edu.pl/downloads/zydokomuna zawadzka.pdf (20.03.2013). 